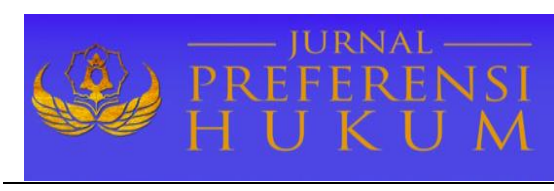

Jurnal Preferensi Hukum | ISSN: 2746-5039

Vol. 2, No. 1 -Februari 2021, Hal. 150-155| Available online at https://www.ejournal.warmadewa.ac.id/index.php/juprehum

DOI: https://doi.org/10.22225/jph.2.1.3061.150-155

\title{
PERKAWINAN YANG TIDAK DICATATKAN DALAM MASYARAKAT HINDU DI
}

\section{BALI}

\author{
Pande Putu Gita Yani, I Ketut Sukadana, Luh Putu Suryani \\ Fakultas Hukum Universitas Warmadewa, Denpasar-Bali, Indonesia
}

\begin{abstract}
Abstrak
Dalam Pasal 2 UU tentang Perkawinan, bahwa perkawinan dianggap sah apabila dilakukan menurut agama dan kepercayaannya, serta didaftarkan ke catatan sipil. Proses perceraian yang tidak dicatatkan dalam masyarakat Hindu di Bali dan akibat perkawinan yang tidak dicatatkan dalam masyarakat Hindu di Bali. Penelitian ini bertujuan untuk mengetahui perceraian yang perkawinannya tidak di catatkan dalam masyarakat Hindu di Bali dan mengetahui akibat perkawinan yang tidak dicatatkan dalam masyarakat Hindu di Bali Metode penelitian yang digunakan adalah jenis penelitian normative, penelitian hukum yang mengkaji hukum tertulis dan terbagi aspek. Hasil analisis menunjukan bahwa seiring berjalannya waktu seringkali timbul permasalahan serta ketidak harmonisan dalam kehidupan rumah tangga, sehingga timbul sebuah perceraian, perceraian merupakan akhir dari suatu perkawinan. Dalam UU No. 1 Tahun 1974 putusnya ikatan perkawinan dapat disebabkan karena kematian, perceraian, dan atas putusan pengadilan. Dalam Persidangan perkara perceraian tidak memiliki akta perkawinan maka dapat diganti dengan Surat keterangan dari kelurahan. Kesimpulannya pada ajaran Hindu sesungguhnya sangat melarang perceraian antara pasangan, terkecuali suami atau istri berkhianat dan tidak setia. Itupun tergantung pada konteksitas terhadap pelanggaran Satyeng Lhaki atau Satyeng Wadon. Tidak hanya itu, perempuan yang tidak mencatatkan perkawinannya lebih banyak mendapat kerugian baik secara sosial, hukum dan kehilangan hak asuh anak.
\end{abstract}

Kata kunci: Perceraian, Akta Perkawinan, Masyarakat Hindu

\begin{abstract}
In Article 2 of the Law on Marriage, that a marriage is considered valid if it is carried out according to religion and belief, and is registered in the civil registry. Divorce proceedings that are not registered in the Hindu community in Bali and as a result of marriages that are not registered in the Hindu community in Bali. This study aims to determine the divorce whose marriage is not recorded in the Hindu community in Bali and to find out the consequences of marriage that is not recorded in the Hindu community in Bali. The research method used is the type of normative research, legal research that examines written law and divided aspects. The results of the analysis show that over time problems and disharmony often arise in domestic life, resulting in a divorce, divorce is the end of a marriage. In Law no. 1 of 1974 the breaking of the marriage bond can be caused by death, divorce, and on court decisions. In divorce proceedings that do not have a marriage certificate, it can be replaced with a certificate from the sub-district. In conclusion, Hinduism actually prohibits divorce between spouses, unless the husband or wife is treasonous and unfaithful. That too depends on the context of the Satyeng Lhaki or Satyeng Wadon violations. Not only that, women who do not register their marriages suffer more losses both socially, legally and lose custody of children.
\end{abstract}

Keywords: Divorce, Marriage Certificate, Hindu Society

\section{PENDAHULUAN}

Perkawinan ialah kasih sayang kesenangan. Hubungan cinta. Merupakan sarana terciptanya kebahagiaan dan kerukunan. Hubunga perkawinan merupakan untuk membentuk keluarga yang kekal serta bahagia. Dengan demikian menegakkan keluarga yang bahagia dan menjadi sendi dasar dari susunan masyarakat, suami istri memikul suatu tanggung jawab dan kewajiban.

Perkawinan pada dasarnya bertujuan untuk kerjasama kehidupan antara pria dan wanita di dalam masyarakat dibawah suatu peraturan khas serta khusus. hal ini sangat diperhatikan dengan baik oleh negara, agama maupun Adat, yang dimana artinya bahwa dari peraturan tersebut bertujuan untuk mengumumkan status baru kepada orang lain sehingga pasangan ini diterima dan diakui statusnya sebagai pasangan yang sah menurut agama, baik hukum, hukum adat maupun Negara dengan sederetan hak dan kewajiban untuk dijalankan oleh keduanya sehingga pria itu bertindak sebagai suami sedangkan wanita bertindak sebagai istri. Perkawinan merupakan suatu peristiwa yang penting 
dalam hidup, karena perkawinan iyalah suatu penunjang untuk meneruskan keturunan. Perkawinan dinyatakan sah apabila telah dilakukan dengan kepercayaan serta agamanya masiing masimg. Perkawinan juga didaftarkan dalam catatan sipil, bahwa pernah ada perkawinan. Perkawinan ini tidak didaftarkan di dalam catatan sipil maka perkawinan tersebut tidak dapat membuat akta perkawinan, perkawianan tersebut tetap sah namun sah secara adat (Surpha, 2004:12)

Perkawinan ialah ikatan lahir batin diantara seorang wanita dengan pria sebagai suami istri karena setiap orang tidak bisa hidup sendiri. Sehingga harus membentuk keluarga dengan tujuan membentuk keluarga yang kekal serta bahagia berdasarkan Ketuhanan Yang Maha Esa. Rumusan perkawinan di atas merupakan rumusan UU tentang Perkawinan..Ketidakharmonisan dalam suatu rumah tangga biasanya disebabkan oleh faktor kesetiaan dan kepercayaan dalam membangun keluarga serta kurangnya komunikasi antara suami istri.Tetapi ada juga diantaranya beberapa kasus perceraian yang disebabkan oleh faktor ekonomi seperti misalnya suami yang tidak bekerja sehingga tidak bisa menafkahi istri dan anak-anaknya.

Berikut ini beberapa penelitian terdahulu yang mengkaji permasalahan tentang perkawinan seperti Dyatmikawati (2011); Adnyana, Windia, \& Sudantra (2012). Perceraian ialah suatu proses yangdimana sebelumnya pasangan tersebut sudah (pasti) berusaha untuk mempertahankannya namun mungkin jalan terbaiknya yang harus ditempuh dengan jalan "perceraian". Biasanya perceraian sering terjadi untuk terhindarnya dari KDRT, untuk perlindungan anak-anaknya yang masih balita, untuk masa depan anak-anaknya, atau malah untuk mendapatkan keturunan.Perceraian ialah sebuah perkawinan, dimana perkawinan sering terjadi pertengkaran, ketidakcocokan, kegagalan, terkadang merasa tidak bahagia ataupun masalah lainnya, bahkan sering ingin untuk mengakhiri (Soimin, 2001:24). Perceraian sering terjadi karena alasan-alasan yang yang sudah jumlah antara seperti memberi pelajaran kepada pasangan bahkan itu dijadikan jalan keluar dari suatu masalah, dimana penyebab perceraian yang sering kita lihat adalah dimana salah satu pasangan menghianati pasangannya, bahkan ketidak cocokan, serta kegagalan dalam berkomunikasi (Lestawi, 1999:4). Berdasarkan latar belakang di atas, penelitian ini bertujuan untuk mengetahui proses perceraian yang perkawinannya tidak di catatkan dalam masyarakat Hindu di Bali dan mengetahui akibat perkawianan yang tidak dicatatkan dalam masyarakat Hindu di Bali.

\section{METODE PENELITIAN}

Penelitian ini didesain dengan menggunakan metode penelitian hukum normative. Penelitian hukum normative adalah penelitian hukum yang mengkaji hukum tertulis dan terbagi aspek, yaitu aspek teori, sejarah, filosofi, perbandingan struktur dan komposisi, lingkup dan materi, konsistensi, penjelasan umum dan pasal demi pasal, formalitas dan kekuatan mengikat suatu undang undang, serta Bahasa hukum yang digunakan (Muhamad, 2006:82).

Adapun sumber hukum yang digunakan dalam penelitian ini terdiri atas 2 bentuk yaitu (1) bahan hukum primer yaitu bahan hukum yang mempunyai kekuatan yang mengikat secara umum (perundang-Undangan) atau mempunyai kekuatan yang mengikat bagi pihak yang berkepentingan (kontrak, konvensi, dokumen hukum atau putusan hakim). Dalam penelitian ini, sumber bahan hukum primer terdiri dari peraturan perundang-undangan tentang perceraian yaitu Undang-Undang Nomor 1 Tahun 1974 tentang perkawinan dan (2) bahan hukum sekunder, yaitu memberikan penjelasan mengenai bahan hukum primer, misalnya buku buku hukum kekeluargaan yang khususnya tentang perkawinan dan perceraian.

Teknik pengumpulan bahan hukum yang digunakan adalah teknik dokumentasi yang dilakukan dengan cara menginventarisasi bahan-bahan hukum baik berupa peraturan perundang-undangan literatur-literatur maupun bahan hukum lainnya yang berkaitan dengan perkawinan dan perceraian yang dimana perkawinan yang harus di daftarkan dicatatan sipil dan membuat akta perkawinan.

\section{HASIL DAN PEMBAHASAN}

\section{Pengertian dan Sahnya Perkawinan Dalam Hukum Hindu}

Perkawinan ialah suatu yang disakralkan dan perkawinan ialah hubungan antara pria dan wanita dan dimana suatu hubungan yang dilandasi oleh cinta, dan kasih sayang. Perkawinan adalah pertemuan antara kamanjaya dan kamaratih atau pertemuan antara sperma dan ovum. Maksud dari perkawinan tersebut adalah untuk menghindari bibit dari pengaruh buruk atau hal negative dari luar. Sehingga 
dapat melahirkan putra yang suputra dan anak yang memiliki budi luhur. Dan perkawinan tersebut mampu menetralisir aura negative.

Dalam UU Perkawianan pasal 1 menyebutkan dimana perkawinan iyalah ikatan antara pria dan wanita dimana mereka saling mengikatkan diri dan saling memiliki satu Sama lain, dengan memiliki tujuan untuk membantu suatu keluarga yang harmonis dan bahagia kekal abadi. Dan sebelum perkawinan terjadi dimana seorang pria harus memiliki restu dari orang tua begitu pula dengan seorang wanita yang harus memiliki izin restu dari orang tua, karena perkawinan tidak boleh dilakukan karena paksaan ataupun dipengaruhi karena dasar lain. Karena itu untuk menghindari terjadinya suatu kerenggangan dan suatu pertengkaran hingga terjadinya suatu perceraian yang sangat di benci oleh tuhan. Dan dalam rumah tangga juga di perlukan adanya suatu kerja Sama dan saling membatu antara suami dan istri dan bisa saling menghagai pasangannya.

Menurut hukum adat Bali perkawinan adalah suatu tanggung jawab yang harus secara mental memahami makna suatu perkawinan sehingga mereka dapat bertanggung jawab. Perkawinan dalam hukum adat Bali sangat menghubungkan dan mengaitkan dengan keluarga dan adat, karena di Bali jika sudah kawin harus bisa memilah dan juga harus bisa menyama braya karena setiap orang yang sudah kawin memiliki ayahan banjar atau petedunan. Dan dalam perkawinan harus bisa melanjutkan garis keturunan, perkawianan juga peristiwa dimana masuknya orang baru dalam keluarga dan ikut memiliki tanggung jawab penuh dalam keluarga. Dalam hukum adat Bali juga ada yang namanya kasta dimana setia orang harus mempertahankan kedudukannya, nanun ada juga yang kluar dari kastanya sehingga mereka lepas dari kedudukannya yang sebenarnya. Dan sring menjadi permasalahan dalam kehidupan bermasyarakat.

Selain perkawinan mengenai bentuk perkawinan perkawianan yang Beda kasta sudah yang secara hukum dibebaskan yang di atur dalam keputusan DPRD Bali No. 11/1951. Namun di masyarakat masih menyisakan sederetanorang yang masih mempertahankan kedudukannya dan sangat kokoh dalam pendiriannya untuk mempertahan kastanya dan sangat memaksakan untuk mengawinkan anak anaknya dengan orang yang berkasta Sama dengannya (Usman, 2010:23).

Kata sahnya suatu perkawinan APA bila perkawinan tersebut sudah dilakukan secara agama dan melengkapi administrasi di Kantor catatan sipil. Karena setiap perkawinan yang sah harus adanya pemberitahun kepada pihak tertentu, perkawinan juga dikatakan sah harus dilakukan berdasarkan restu orang tua (Pudja \& Sudharta, 2002:551). Menurut UU Perkawinan, sahnya suatu perkawinan adalah sesuai hukum agama masing-masing.Jadi perkawinan yang sah menurut hukum perkawinan nasional adalah perkawinan yang dilaksanakan menurut tata tertib aturan hukum yang berlaku dalam agama Hindu. Jadi dalam agama Hindu misalnya yang terjadi didesa Apuan yaitu pertamanya dilakukan ngidih atau mepadik kerumah mempelai wanita, dan dilakukian metanjung sambuk dan dilakukannya yang di sebutmebiakalamekalan kalan dan metataban di bale adat. Dan setelah itu dilakukan acara mepejati atau mepamit di rumah yang wanita. Jadi setiap perkawianan juga dilakukan berdasarkan awig awig adat yang berlaku disetiap banjarnya. Dan sebelum tiga hari dari acara perkawinan belum boleh keluar karena dinyatakan sebagai sebet kandel atau sebel nganten.

Dalam Hukum Hindu dijelaskan sistem perkawinan di Indonesia dianggap sah selain telah memenuhi aturan dan syarat yang berlaku dan telah di lakukan administrasi sesuai aturan yang berlaku. Oleh karena itu dalam setiap perkawinan, harus dilakukan pencatatan perkawinan oleh petugas catatan sipil. Hal tersebut ditegaskan dalam UU Perkawinan yang di tegaskan dalam pasal 2 ayat 1 dan 2: "Perkawinan adalah sah, apabila dilakukan menurut hukum masing-masing agamanya dan kepercayaan itu serta tiap-tiap perkawinan dicatat menurut peraturan perundang-undangan yang berlaku".

Ajaran Hindu sebenarnya melarang adanya perceraian antara pasangan, kecuali suami atau istri berkhianat dan tidak setia. Itupun tergantung pada konteksitas terhadap pelanggaran Satyeng Lhaki atau Satyeng Wadon. Perceraian merupakan akhir dari suatu perkawinan .Ketika suatu perkawinan sering trjadi perdebatan, merasa tidak bahagia, danketidaksetiaan pasangan, atau masalah lainnya, serin terpikir untuk segera mengakhiri pernikahan tersebut. Bercerai dengan pasangan hidup dianggap sebagai solusi terbaik bagi banyak pasangan yang perkawinan walaupun mereka tahu perbuatan perceraian adalah perbuatan yang dibenci Tuhan. Alasan lain bercerai adalah memberi pasangan hidup pelajaran sebagai jalan keluar yang baik untuk mengakhiri rasa sakit hati. Tetapi, dengan bercerai tidak berarti bebas dari masalah. Beberapa faktor yang menyebabkan perceraian itu terjadi, antara lain: 
1. Gagal berkomunikasi

2. Ketidaksetian

3. Kekerasan dalam Rumah Tangga

4. Masalah Ekonomi

5. Perkawinan Dini

6. Perubahan Budaya

Dalam Undang-Undang Nomor 1 Tahun 1974, tentang perkawinan perceraian dapat disebabkan oleh kematian, penghianatan dan putusanya dalam persidangan. Artinya, perceraian itu sah apabila dilakukan di pengadilan. Sebuah masyarakat proses perceraiansecara adat di dalam lingkungan masyarakat, penelitian pada salah satu Desa Pakraman yang ada di Bali yaitu tepatnya Desa Pakraman Apuan, yang merupakan salah satu desa pakraman yang terletak di Kecamatan Susut, Kota Bangli. Menurut Bendesa Adat Desa Pakraman Apuan, di desa tersebut pernah beberapa kali terjadi perceraian secara adat antara karma (warga) desa tersebut. Proses perceraian secara adat di awali dengan Pasangan suami istri yang sudah dengan keinginan yang keras untuk bercerai pertama harus membuat suatu pernyataan, dimana dalam Surat pernyataan perceraian tersebut isinya sudah sangat jelas tentang alasan-alasan perceraian maupun Hak Asuh si anak (kalau punya anak). Setelah kedua belah pihak sama-sama sudah mengetahui isi dari surat pernyataan tersebut, jika memang tidak ada yang perlu harus ditambah ataupun dikurangi dari isi pernyataan tersebut maka surat pernyataan perceraian tersebut ditanda tangani oleh kedua belah pihak dengan bermaterai 6.000, - Perlu dijelaskan posisi Kepala Dusun adalah pengganti Kepala Desa karena yang bercerai tidak memiliki Akta Perkawinan dan yang menyaksikan proses upacara perkawinan tersebut adalah kepala dusun.

Bilamana yang bercerai telah memiliki akta perkawinan proses perceraian adat ini bisa dipakai dasar untuk mengajukan gugatan perceraian ketingkat Pengadilan Negeri. Dengan tambahan pihak Kepala Desa ikut mengetahui perceraian tersebut. Di dukung kuat oleh pendapat hakim perceraian yang tidak dapat menunjukkan alat bukti seperti akta perkawinan maka dapat di gantikan dengan Surat keterangan dari kepala desa/lurah bahwa pernah ada perkawinan yang tidak didaftarkan atau tidak memenuhi persyaratan administrasi dan tidak dicatatkan dalam catatan sipil. Jadi perceraian tersebut dapat dilaksanakan apabila sudah mendapat Surat keterangan. Karena pejabat yang berada di desa tidak dapat memutus perceraian, perceraian hanya dapat diputus oleh hakim, sekalipun perkawinan tersebut tidak memiliki akta perkawinan.

\section{Kekuatan Hukum Alat Bukti Akta Perkawinan Dalam Proses Perceraian}

Menurut bentuknya akta dapat dibagi menjadi akta otentik dan akta di bawah tangan. Akta otentik adalah akta yag dibuat oleh pejabat yang diberi wewenang untuk itu oleh penguasa, menurut ketentuan-ketentuan yang telah ditetapkan, baik dengan maupun tanpa bantuan dari yang berkepentingan lihat pasal $165 \mathrm{HIR}, 1868 \mathrm{BW}$, dan $285 \mathrm{Rbg}$. Akta di bawah tangan ialah akta yang sengaja dibuat untuk pembuktian oleh para pihak tanpa bantuan dari seorang pejabat. Dengan kata lain dapat diartikan bahwa Akta otentik adalah akta yang dibuat dan dipersiapkan oleh notaries/PPAT, camat dan/atau pejabat resmi lainnya (Harwathy, 2011:24).

Pejabat resmi lainnya atau Pegawai umum yang dimaksud dapat berlaku pada seorang hakim, juru sita pada suatu pengadilan, pegawai catatan sipil, dan sebagainya. Dengan demikian maka suatu akta notaris, suatu Surat putusan hakim, suatu Surat proses verbal yang dibuat oleh seorang juru sita pengadilan dan suatu akta perkawinan yang dibuat oleh pegawai catatan sipil adalah termasuk ke dalam akta-akta otentik. Perceraian terjadi sebagai akibat dari adanya suatu perkawinan yang sah menurut undang-undang. Dan menurut agama Hindu terkait proses pembuktian dalam persidangan perkara perceraian apabila pasangan suami istri tidak memiliki bukti surat berupa akta perkawinan atau dengan kata lain perkawinan mereka belum dicatatkan pada Kantor Dinas Kependudukan dan Catatan Sipil maka Akta Perkawinan sebagai alat bukti otentik bisa digantikan dengan surat keterangan dari kelurahan yang menyatakan bahwa memang benar telah terjadi perkawinan yang sah antara suami istri bersangkutan yang dilangsungkan secara agama hindu dan diterangkan pula waktu dan tempat berlangsungnya perkawinan tersebut.

Perkawinan yang tidak dicatatkan ternyata, defacto dan dalam kasus konkrit bukan bentuk yang sederhana dan tunggal.Bahkan, dalam bentuk tertentu sudah merupakan perbuatan sindikasi yang bersentuhan dengan aspek sosial, ekonomi, kultural dan tentu saja hukum. Berbagai kasus kejahatan perdagangan orang yang terungkap ke media, ternyata perkawinan yang tidak dicatatkan karena 
pernikahan paksa, atau perbudakan berkedok pernikahan (servile marriage) sebagai modus perdagangan anak dan perempuan. Perkawinan yang tidak dicatatkan dalam masyarakat Hindu di Bali banyak di jumpai pada orang tua, dimana perkawinan yang tidak dicatatkan tidak dapat dikatakan sah, karena tidak terdaftar dalam catatakan perkawinan masyarakat yang terdapat di desa tersebut, perkawinan dalam hukum Hindu harus mengukuti awig-awig yang mengatur di suatu desa. Perkawinan yang tidak dicatatkan dapat dikatakan sebagai kawin kontrak yang hanya berlangsung beberapa saat dan tidak dapat di akui oleh masyarakat Hindu (Rasaid, 1995:7). Jika perkawinan yang hanya di hadiri oleh kepala Dusun dan tidak didaftarkan kepada kepala desa maka perkawinan tersebut dapat dikatakan sah menurut masyarakat Hindu, namun tidak menurut UU Nomor 1 Tahun 1974 karena tidak melengkapi kriteria perkawinan yaitu tidak memenuhi administrasi di kantor catatan sipil.

\section{SIMPULAN DAN SARAN \\ 1. Simpulan}

Ajaran Hindu sesungguhnya sangat melarang perceraian antara pasangan, terkecuali suami atau istri berkhianat dan tidak setia. Itupun tergantung pada konteksitas terhadap pelanggaran Satyeng Lhaki atau Satyeng Wadon. Menurut Reg Weda, sudah sangat salah kalau bercerai atau berpisah, karena sudah melanggar Yadnya yang sangat susah dilakoni secara materiil, moril, dan spiritual dan melanggar sumpah yang telah diucapkan dalam acara perkawinan. Perlu Mulat Sarira atau intropeksi diri antara pasangan suami istri yang berkhianat dan tidak setia. Pasangan yang ingin bercerai harus membuat Surat Pernyataan bahwa pernah ada perkawinan dan membawa saksi yang mengetahui perkawinan tersebut dan mengetahui bahwa pasangan suami istri tersebut telah sepakat akan bercerai. Selanjutnya, disampaikan secara lisan terhadap masyarakat bahwa pernah ada perkawinan dan akan bercerai. Kemudian, perkawinan yang tidak dicatatkan sangat merugikan bagi seorang istri dan anak dari perkawinan itu, baik dilihat secara hukum maupun secara sosial. Secara hukum, sehingga perempuan tidak lagi dianggap sebagai istri sah. Dengan itu, dia tidak berhak atas nafkah dan warisan dari suami jika ditinggal meninggal dunia. Selain itu, sang istri dan anak juga tidak berhak atas harta gono-gini jika terjadi perceraian, karena secara hukum perkawinan tersebut dianggap tidak pernah terjadi. Sehingga, dilihat dari segi sosial, perempuan yang perkawinan yang tidak dicatatkan sering dianggap menjadi istri simpanan. Selain itu, status anak yang dilahirkan dianggap sebagai anak tidak sah. Karena tidak adanya pendaftaran perkawinan secara sah.

\section{Saran}

Melalui penelitian ini diharapkan sosialisasi yang lebih serius dari pemerintah supaya kesadaran hukum masyarakat meningkatkan tentang pentingnya proses pencatatan perkawinan dan memberikan pemahaman kepada masyarakat tentang sahnya perkawinan menurut Undang-Undang No 1 Tahun 1974 Tentang Perkawinan. Kemudian, biaya perceraian yang dianggap masih terlalu mahal bagi masyarakat khususnya masyarakat pedesaan yang masih tergolong miskin menyebabkan beberapa masyarakat memilih bercerai secara adat saja. Oleh karena itu, pemerintah hendaknya bisa memberikan pelayanan hukum yang mudah kepada masyarakat, walaupun ada proses berperkara secara prodeo yang dibiayai pemerintah namun hal tersebut belum sepenuhnya diketahui dan bisa dirasakan oleh masyarakat serta cenderung membutuhkan waktu yang lebih lama.

\section{DAFTAR PUSTAKA}

Adnyana, I. W. P., Windia, I. W., \& Sudantra, I. K. (2012). Perkawinan Nyeburin Berbeda Agama Ditinjau dari Hukum Adat Bali (Studi Kasus di Banjar Dakdakan, Desa Pakraman Kelaci Kelod, Kabupaten Tabanan). E-Journal Ilmu Hukum: Kertha Wicara, 1(1), 1-10.

Dyatmikawati, P. (2011). Perkawinan pada Gelahang dalam Masyarakat Hukum Adat di Provinsi Bali Ditinjau dari Undang-Undang No. 1 Tahun 1974 tentang Perkawinan. DIH, Jurnal Ilmu Hukum, 7(14), 107-123.

Harwathy, T. I. S. (2011). Hukum Perdata. Denpasar: Universitas Mahasaraswati.

Lestawi, I. N. (1999). Hukum Adat. Surabaya: Paramita.

Muhamad, A. (2006). Hukum dan Penelitian Hukum. Bandung: PT. Citra Bakti.

Pudja, \& Sudharta. (2002). Hukum Perkawinan Hindu yang Diresepsir ke dalam Hukum Adat Bali dan Lombok. Jakarta.

Rasaid, M. N. (1995). Hukum Acara Perdata. Jakarta: Sinar Gafika.

Soimin, S. (2001). Hukum Orang dan Keluarga. Jakarta: Sinar Grafika. 
Jurnal Preferensi Hukum

Vol. 2, No. 1, 2020

Surpha, I. W. (2004). Eksistensi Desa Adat dan Desa Dinas di Bali. Denpasar: Pustaka Bali Post.

Usman, H. A. (2010). Titik Singgung Kewenangan Pengadilan Dalam Lingkungan Peradilan Umum dan

Peradilan Agama. Jakarta: Balitbang Pendidikan dan Pelatihan Hukum dan Peradilan Mahkamah Agung RI.

UU Nomor 1 Tahun 1974 Tentang Perkawinan

Kitab Undang-Undang Hukum Perdata 